\title{
The associations between postpartum serum haptoglobin concentration and metabolic status, calving difficulties, retained fetal membranes, and metritis
}

\author{
A. Pohl, O. Burfeind, and W. Heuwieser ${ }^{1}$ \\ Clinic of Animal Reproduction, Faculty of Veterinary Medicine, Freie Universität Berlin, Königsweg 65, 14163 Berlin, Germany
}

\begin{abstract}
Measurement of serum haptoglobin (Hapto) concentrations results in only moderate reported specificity and sensitivity for the detection of metritic cows. The objective of this study was to evaluate associations between different variables and haptoglobin concentrations after calving. Parity, periparturient metabolic stress indicated by $\beta$-hydroxybutyric acid (BHBA) and nonesterified fatty acids (NEFA), calving difficulties, retained fetal membranes (RFM), and acute puerperal metritis (APM) were evaluated. A total of 443 Holstein Friesian cows were enrolled in this retrospective observational study. Acute puerperal metritis was diagnosed when a cow had fetid, reddish-brown, watery vaginal discharge in combination with rectal temperature $\geq 39.5^{\circ} \mathrm{C}$. The retention of the fetal membranes has been defined as the failure to expel the fetal membranes within $12 \mathrm{~h}$ after calving. Results of blood samples from 2 and $5 \mathrm{~d}$ in milk (DIM) were analyzed for Hapto, BHBA, and NEFA. Primiparous cows had a greater median Hapto concentration than multiparous cows at 5 DIM [primiparous: $2.25 \mathrm{~g} / \mathrm{L}$, interquartile range (IQR) $1.45-2.50, \mathrm{n}$ $=146$; multiparous: $1.13 \mathrm{~g} / \mathrm{L}, \mathrm{IQR} \quad 0.52-2.22, \mathrm{n}=302$; $P<0.05]$. Therefore, different Hapto thresholds based on references from literature for all cows $(1.4 \mathrm{~g} / \mathrm{L})$, primiparous cows $(2.49 \mathrm{~g} / \mathrm{L})$, and multiparous cows $(1.4 \mathrm{~g} / \mathrm{L})$ were used for further analysis. Periparturient metabolic stress indicated by elevated BHBA $(\geq 1.2$ $\mathrm{mmol} / \mathrm{L})$ at 5 DIM was associated with elevated Hapto (odds ratio 2.39-2.87) regardless of parity. In contrast, elevated NEFA $(\geq 0.6 \mathrm{mmol} / \mathrm{L})$ at 2 DIM was not a risk factor for elevated Hapto. Multiparous cows with assisted calving had a 2.46 times higher risk for elevated Hapto, whereas primiparous cows with assisted calving had no elevated risk for elevated Hapto at 5 DIM. Moreover, multiparous cows with RFM were 5.51 times more likely to have elevated Hapto at 5 DIM than cows
\end{abstract}

Received December 2, 2014.

Accepted March 19, 2015.

${ }^{1}$ Corresponding author: w.heuwieser@fu-berlin.de without RFM. Acute puerperal metritis within the first 5 DIM was associated with elevated Hapto (odds ratio 2.74-5.01), regardless of parity. We speculate that the association of calving ease, RFM, and periparturient metabolic stress could explain the moderate sensitivity and specificity reported for the detection of metritic cows by measuring Hapto.

Key words: haptoglobin, calving, retained fetal membranes, metabolic stress, acute puerperal metritis

\section{INTRODUCTION}

The transition period is associated with an elevated incidence of metabolic and infectious diseases because parturition and the onset of lactation represent huge challenges to the immune system and metabolism of the postpartum cow (Goff and Horst, 1997; Hammon et al., 2006; LeBlanc, 2008). In particular, cows with calving disorders such as dystocia, twins, and caesarian section are predisposed to develop metritis because human intervention is usually necessary, and increased contamination of the uterus during manual examination and extraction is hard to avoid (Dubuc et al., 2010). It is also known that cows with retained fetal membranes (RFM) are more likely to develop metritis than cows without RFM (Halpern et al., 1985; Bruun et al., 2002). Furthermore, metabolic diseases (e.g., ketosis-fatty liver complex) during early lactation are associated with a higher risk of metritis (Duffield et al., 2009). Within the first days of lactation, cows cannot obtain enough energy from dietary sources to meet their needs for body tissue and milk production, resulting in body fat mobilization as well as negative energy balance (Goff and Horst, 1997). The liver's capacity to metabolize fatty acids during lipolysis is limited. When reaching this limit, NEFA and ketone bodies (e.g., acetoacetate, acetone, and BHBA) accumulate in the blood (Goff and Horst, 1997; Doepel et al., 2002). Because NEFA supply substrates for BHBA, this parameter is usually elevated earlier than BHBA (Doepel et al., 2002).

Negative energy balance has a suppressive effect on immune function. Hammon et al. (2006) found an as- 
sociation between impairment of neutrophil function and negative energy balance. Furthermore, it has been demonstrated that cows that develop uterine disease experience a greater degree of negative energy balance and have greater neutrophil impairment (Galvão et al., 2010). Neutrophils are the main leukocyte type involved in bacterial clearance after uterine infection, and cows with impaired neutrophil function are predisposed to uterine diseases (Hussain, 1989; Gilbert et al., 2007).

Acute phase response is one defense mechanism of the body against uterine infections (Schneider et al., 2013). Haptoglobin (Hapto) is an acute phase protein synthesized in the liver in response to inflammation (Crawford et al., 2005) and it can be measured in serum. The association between uterine infections and elevated serum Hapto concentrations is well recognized in cows (Huzzey et al., 2009; Dubuc et al., 2010; Burfeind et al., 2014a). Recently, however, our group has shown that the sensitivity to detect acute puerperal metritis (APM) by measuring Hapto in primiparous and multiparous cows was only $64 \%$ (threshold of $2.48 \mathrm{~g} / \mathrm{L}$ ) and $72 \%$ (threshold of $1.39 \mathrm{~g} / \mathrm{L}$ ) at $5 \mathrm{DIM}$, respectively (Burfeind et al., 2014a). Previous studies reported even lower sensitivities (50 and 51.6\%) for thresholds of $1 \mathrm{~g} / \mathrm{L}$ at 3 DIM (Huzzey et al., 2009) and $0.8 \mathrm{~g} / \mathrm{L}$ within the first week postpartum (Dubuc et al., 2010), respectively.

Because Hapto is an indicator of nonspecific innate immune response activated by various inflammatory lesions, different variables can influence Hapto concentrations and reduce sensitivity (Eckersall, 2000; Huzzey et al., 2009; Ceciliani et al., 2012). Experimentally induced fatty liver is associated with increased Hapto concentrations (Uchida et al., 1993), and one conclusion is that increased concentrations of Hapto around parturition could be caused by negative energy balance (Crawford et al., 2005). Little research has been conducted on the association between calving disorders and Hapto concentrations (Sabedra, 2012) but we hypothesized that vaginal and uterine lesions due to calving disorders could result in elevated Hapto. Moreover, RFM could increase inflammatory reactions due to bacterial contamination of the vagina and uterus (Bekana et al.; 1994). To evaluate whether antimicrobial treatment of APM is associated with Hapto, treatment as a variable was included in the analysis. Therefore, the objective of this study was to evaluate whether, in addition to APM, other variables occurring within the first 5 DIM are associated with elevated Hapto at 5 DIM. Specifically, we assessed metabolic stress indicated by elevated NEFA and BHBA serum concentrations, calving difficulties, antibiotic treatment of APM within the first 5 DIM, and RFM.

\section{MATERIALS AND METHODS}

\section{Animals}

A total of 443 Holstein Friesian cows from a commercial dairy farm in Sachsen-Anhalt, Germany, were enrolled in this retrospective observational study. The study was part of 2 research projects involving a clinical trial on body temperature in 2010 (Burfeind et al., 2011, 2014b) and on therapy of APM in 2011 (Sannmann et al., 2013). Cows were managed according to the guidelines set by the International Cooperation on Harmonization of Technical Requirements for Registration of Veterinary Medicinal Products (Hellmann and Radeloff, 2000). The experimental procedures reported herein were conducted with the approval of the Institutional Animal Care and Use Committee of Freie Universität Berlin. The farm housed 1,200 dairy cows. Herd average milk yield was $10,124 \mathrm{~kg} /$ lactation (4.1\% fat, $3.4 \%$ protein) in 2010 and $10,147 \mathrm{~kg} /$ lactation (4.0\% fat, $3.3 \%$ protein) in 2011. All cows were housed indoors. Before calving, cows were housed in group pens with deep-straw bedding. Lactating cows were housed in a freestall barn with cubicles equipped with rubber mats and slatted floors. The groups were separated into primiparous and multiparous cows. A TMR was distributed by conveyer belt system up to 10 times a day. Cows were milked 3 times a day (0600, 1400 , and $2200 \mathrm{~h})$.

\section{Sample Collection}

Acute puerperal metritis was diagnosed when a cow had fetid, reddish-brown, watery vaginal discharge in combination with rectal temperature $\geq 39.5^{\circ} \mathrm{C}$ (Sheldon et al., 2006) within the first 10 DIM. Rectal temperature was measured and recorded daily by study personnel. Cows were examined for vaginal discharge by study personnel introducing a gloved hand into the vaginal cavity at 2,5 , and 10 DIM. Vaginal discharge was classified on a scale from 0 to $2(0=$ no discharge; $1=$ normal lochial secretion, not smelly, viscous, reddishbrown; 2 = fetid, watery, reddish-brown). If antibiotic treatment of APM was required, a single injection of ceftiofur crystalline free acid (Naxcel, Pfizer Ltd., Kent, UK) was administered. In 2010, cows with APM were treated by farm personnel according to a standard operating procedure developed by the herd veterinarian. In 2011, cows were additionally examined for vaginal discharge on days with rectal temperature $\geq 39.5^{\circ} \mathrm{C}$ and treated either on the day of diagnosis ( 1 to 10 DIM) or only from 5 to 10 DIM (Sannmann et al., 2013). All cows that received antimicrobial drugs for purposes 
other than APM within the first 10 DIM (e.g., acute mastitis) were excluded from analysis. In this study, only metritis occurring before or at 5 DIM was analyzed, and antimicrobial treatment of APM before or at 5 DIM was included in the analysis.

Retained fetal membranes were diagnosed by farm personnel if expulsion of fetal membranes occurred more than $12 \mathrm{~h}$ after calving. Information on RFM was recorded by using herd management software (Herde, version 5.71, dsp Agrosoft GmbH, Ketzin, Germany).

All cows had blood collected from the coccygeal vein at 2, 5, and 10 DIM using sterile vacuum tubes (Venoject II, Terumo Europe N.V., Leuven, Belgium). In this study, only results of samples from 2 and 5 DIM were used for analysis.

Immediately after blood collection, BHBA was measured with an electronic BHBA measuring system consisting of a handheld meter (Precision Xtra, Abbott Diabetes Care, Abingdon, UK) and electrochemical test strips (Precision Xtra $\beta$-ketone, Abbott Diabetes Care). After the test strip had been inserted into the meter, blood was applied to the sample chamber. After $10 \mathrm{~s}$, the concentration of BHBA $(\mathrm{mmol} / \mathrm{L})$ was displayed on the meter. Iwersen et al. (2009) validated this method and found a highly significant correlation ( $\mathrm{r}=0.95, P<0.001)$ between whole-blood BHBA concentrations measured by the handheld meter and serum BHBA concentrations measured photometrically in the laboratory. The incidence and prevalence of subclinical ketosis (SCK; BHBA $\geq 1.2 \mathrm{mmol} / \mathrm{L}$ ) peaked at 5 DIM (McArt et al., 2012) or within the first week postpartum (Duffield et al., 1998; LeBlanc, 2010). Therefore, concentrations of BHBA at 5 DIM were used for further analysis. Recent studies have recommended a threshold of $1.2 \mathrm{mmol} / \mathrm{L}$, because it results in a good combination of sensitivity and specificity for metritis occurrence (Duffield et al., 2009; McArt et al., 2013; Suthar et al., 2013). Therefore, in this study, we defined SCK as a BHBA concentration $\geq 1.2 \mathrm{mmol} / \mathrm{L}$.

After BHBA measurement, the blood was allowed to clot. Within $2 \mathrm{~h}$ after sampling, blood samples were centrifuged at $1,000 \times g$ for $10 \mathrm{~min}$ at room temperature and serum stored at $-22^{\circ} \mathrm{C}$ until analysis for serum Hapto and NEFA concentrations. Serum samples were sent to an accredited commercial laboratory (Synlab Laboratories, Berlin, Germany). Burfeind et al. (2014a) showed that Hapto at 5 DIM had the greatest combination of sensitivity and specificity to distinguish between healthy cows and cows with APM. Moreover, serum Hapto concentrations were highest between 3 and 6 DIM depending on the degree of uterine disease (Huzzey et al., 2009) and were elevated in cows with APM compared with a control group (Drillich et al.,
2007). Therefore, Hapto was analyzed from samples collected at 5 DIM. For this analysis, an ELISA (Sunrice Reader; Tecan, Maennedorf, Switzerland) was used. The device has been calibrated by the laboratory using cattle serum with Hapto concentrations between 0.6 and $1.3 \mathrm{~g} / \mathrm{L}$. The lower limit of detection was 0.31 $\mathrm{g} / \mathrm{L}$. All samples with concentrations $<0.31 \mathrm{~g} / \mathrm{L}$ were set to $0.31 \mathrm{~g} / \mathrm{L}$. The upper limit of detection of samples from 2010 was $2.5 \mathrm{~g} / \mathrm{L}$, and all samples from 2010 with concentrations $>2.5 \mathrm{~g} / \mathrm{L}$ were set to $2.5 \mathrm{~g} / \mathrm{L}$. There was no upper limit of detection of samples from 2011.

Because NEFA is usually elevated earlier than BHBA (Doepel et al., 2002), samples collected at 2 DIM were analyzed for NEFA by using a clinical chemistry analyzer (AU 680, Beckman Coulter, Krefeld, Germany) and a test kit from Randox. Concentrations of NEFA were determined by photometric measurement. The lower limit of detection was $0.07 \mathrm{mmol} / \mathrm{L}$. All samples with concentrations $<0.07 \mathrm{mmol} / \mathrm{L}$ were set to 0.00 mmol/L. For postpartum NEFA concentrations, a recent study showed that a threshold of $0.57 \mathrm{mmol} / \mathrm{L}$ is optimal to predict clinical ketosis, metritis, or displaced abomasa (Ospina et al., 2010). Moreover, Hiss et al. (2009) showed an association between NEFA $\geq 0.6$ $\mathrm{mmol} / \mathrm{L}$ and Hapto concentration postpartum. Therefore, we chose a threshold of $0.6 \mathrm{mmol} / \mathrm{L}$ for NEFA.

Information about calving was recorded by farm personnel using the herd management software (Herde, version 5.71, dsp Agrosoft $\mathrm{GmbH}$ ). Calving ease was scored on a 5 -point scale $(0=$ calving not observed, 1 = calving without human intervention, $2=$ calving with soft human pulling, $3=$ dystocia, $4=$ caesarian section or veterinarian-assisted calving). For analysis, the score was reduced to spontaneous calving ( 0 and 1 ) and assisted calving (2 to 4 ).

\section{Statistical Analysis}

Data were analyzed using SPSS for Windows (version 22, SPSS Inc., Munich, Germany). Median concentrations of Hapto and interquartile ranges (IQR) were calculated for different variables. The IQR is the difference between the third and first quartiles in a data set and is a measure of how the data spread around the median. Differences of the absolute concentrations of Hapto between cows with elevated NEFA $(\geq 0.6$ $\mathrm{mmol} / \mathrm{L}$ ) and without elevated NEFA concentrations $(<0.6 \mathrm{mmol} / \mathrm{L})$ at $2 \mathrm{DIM}$, between cows with SCK $(\mathrm{BHBA} \geq 1.2 \mathrm{mmol} / \mathrm{L})$ and without SCK $(\mathrm{BHBA}<1.2$ $\mathrm{mmol} / \mathrm{L}$ ) at $5 \mathrm{DIM}$, between cows with spontaneous calving and assisted calving, between cows with and without RFM, between cows with and without antimicrobial treatment within the first 5 DIM, and between 
cows with or without metritis within the first 5 DIM were compared by using the Mann-Whitney U-test. A $P$-value $<0.05$ represents significant differences between groups.

To determine the association between different variables and elevated Hapto at 5 DIM, we first tested the effect of the factors of interest on Hapto separately with Mann-Whitney U-tests to identify those factors that should be included in the binary logistic regression model. Therefore, parity $(1=$ primiparous, $2=$ multiparous), NEFA $(0=<0.6 \mathrm{mmol} / \mathrm{L}, 1=\geq 0.6$ $\mathrm{mmol} / \mathrm{L})$, SCK $(0=\mathrm{BHBA}<1.2 \mathrm{mmol} / \mathrm{L}, 1=\mathrm{BHBA}$ $\geq 1.2 \mathrm{mmol} / \mathrm{L})$, calving $(0=$ spontaneous, $1=$ assisted), RFM (0 = no, $1=$ yes $)$, antimicrobial treatment $(0=$ no, $1=$ yes $)$, and $\operatorname{APM}(0=$ no, $1=$ yes $)$ were tested, and only variables with $P<0.20$ were included in a binary logistic regression model. Furthermore, all variables were tested with Spearman's correlation. If 2 variables showed a high, significant correlation (r $>0.5$ ), only the one resulting in the Mann-Whitney U-test with the smaller $P$-value was used in the final model (Bertulat et al., 2013). The binary regression model was constructed in a stepwise backward manner such that in the final binary regression model variables with $P>0.05$ were excluded. Odds ratios, confidence intervals, and $P$-values are reported. Confidence interval was set at $95 \%$.

To evaluate associations, 3 different approaches were investigated. To account for different Hapto thresholds in primiparous and multiparous cows to distinguish between healthy and metritic cows (Burfeind et al., 2014a), animals were classified according to parity. In the first approach, all cows were included and the Hapto threshold was $1.4 \mathrm{~g} / \mathrm{L}$. In the second approach, only primiparous cows were included and the threshold of Hapto was $2.49 \mathrm{~g} / \mathrm{L}$. In the third approach, only multiparous cows were included and the Hapto threshold was $1.4 \mathrm{~g} / \mathrm{L}$. Thresholds were based on a receiver operating characteristic curve analysis by Burfeind et al. (2014a), which demonstrated that different Hapto thresholds for metritis detection are optimal depending on parity, and that primiparous cows have higher Hapto concentrations than multiparous cows. Except for the variable parity, all mentioned variables were also evaluated using the second and third approaches.

\section{RESULTS}

Primiparous cows $(2.25 \mathrm{~g} / \mathrm{L}$, IQR $1.45-2.50, \mathrm{n}=$ 146) had greater median Hapto concentrations than multiparous cows $(1.13 \mathrm{~g} / \mathrm{L}, \mathrm{IQR} 0.52-2.22, \mathrm{n}=297$; $P<0.05)$. Differences between Hapto concentrations considering different variables are presented in Table
1. We detected no difference in Hapto concentrations in primiparous cows between spontaneous and assisted calving $(P=0.40)$, between primiparous cows with RFM and without RFM $(P=0.37)$, or between primiparous cows with and without antimicrobial treatment $(P=0.10)$. Concentrations of Hapto at 5 DIM differed depending on the occurrence of elevated NEFA at 2 DIM, SCK at 5 DIM, and APM in primiparous and multiparous cows $(P<0.05)$. Moreover, multiparous cows with assisted calving and antimicrobial treatment within 5 DIM had higher Hapto concentrations than those with spontaneous calving or without antimicrobial treatment $(P<0.05)$.

The binary logistic regression analysis was conducted to determine the association between different variables and elevated Hapto at 5 DIM. Calving ease, RFM, and NEFA at 2 DIM are variables occurring before Hapto measurement and therefore are possible risk factors for elevated Hapto. As BHBA was measured at 5 DIM and APM could occur within the first 5 DIM, increased odds ratios reflect associations instead of risks between these variables and elevated Hapto because the condition for causality is not given. Treatment before or at 5 DIM was highly correlated with APM within the first 5 DIM ( $\mathrm{r}>0.5, P<0.05)$. Acute puerperal metritis was selected for inclusion in the final model because it was the variable of special interest in this study.

In the first approach, all cows were included in the final logistic regression model (Table 2). Remaining variables were parity, BHBA at 5 DIM, calving ease, RFM, and APM. Primiparous cows, cows with BHBA $\geq 1.2 \mathrm{mmol} / \mathrm{L}$ at $5 \mathrm{DIM}$, cows with assisted calving, cows with RFM, and cows with APM had $4.4(P<$ $0.05), 2.87(P<0.05), 1.95(P<0.05), 3.39(P<0.05)$, and $4.7(P<0.05)$ times the odds of elevated Hapto $(\geq 1.4 \mathrm{~g} / \mathrm{L})$ compared with multiparous cows, cows with $\mathrm{BHBA}$ at $5 \mathrm{DIM}<1.2 \mathrm{mmol} / \mathrm{L}$, cows with spontaneous calving, cows without RFM, and cows without APM within 5 DIM, respectively.

In the second approach, only primiparous cows were included in the binary logistic regression model (Table 3 ), and the threshold for Hapto at 5 DIM was set at $2.49 \mathrm{~g} / \mathrm{L}$. Only SCK and APM remained significant in the final model. Cows with BHBA $\geq 1.2 \mathrm{mmol} / \mathrm{L}$ at 5 DIM and cows with APM within 5 DIM had $2.39(P$ $<0.05)$ and $2.74(P<0.05)$ times the odds of elevated Hapto $(P<0.05)$.

In the third approach, only multiparous cows were included in the binary logistic regression model (Table 4), and the threshold for Hapto at 5 DIM was set at $1.40 \mathrm{~g} / \mathrm{L}$. Remaining variables were SCK, calving ease, RFM, and APM. Cows with BHBA $\geq 1.2 \mathrm{mmol} / \mathrm{L}$ at 5 DIM, cows with assisted calving, cows with RFM, and 
Table 1. Differences in median haptoglobin concentration $(\mathrm{g} / \mathrm{L})$ at 5 DIM differentiated by parity and considering NEFA at 2 DIM, BHBA at 5 DIM, calving ease, retained fetal membranes, antimicrobial treatment $\leq 5$ DIM, and acute puerperal metritis $\leq 5$ DIM

\begin{tabular}{|c|c|c|c|c|c|c|}
\hline Variable & Parity $^{1}$ & Class & No. of cows & Median & $\mathrm{IQR}^{2}$ & $P$-value ${ }^{3}$ \\
\hline \multirow[t]{4}{*}{ NEFA at 2 DIM } & \multirow[t]{2}{*}{1} & $<0.6 \mathrm{mmol} / \mathrm{L}$ & 54 & 1.90 & $1.16-2.50$ & \multirow[t]{2}{*}{$<0.05$} \\
\hline & & $\geq 0.6 \mathrm{mmol} / \mathrm{L}$ & 68 & 2.48 & $1.94-2.50$ & \\
\hline & \multirow[t]{2}{*}{2} & $<0.6 \mathrm{mmol} / \mathrm{L}$ & 124 & 0.96 & $0.45-2.00$ & \multirow[t]{2}{*}{$<0.05$} \\
\hline & & $\geq 0.6 \mathrm{mmol} / \mathrm{L}$ & 145 & 1.34 & $0.56-2.47$ & \\
\hline \multirow[t]{4}{*}{ BHBA at 5 DIM } & \multirow[t]{2}{*}{1} & $<1.2 \mathrm{mmol} / \mathrm{L}$ & 109 & 2.02 & $1.23-2.50$ & \multirow[t]{2}{*}{$<0.05$} \\
\hline & & $\geq 1.2 \mathrm{mmol} / \mathrm{L}$ & 38 & 2.49 & $2.15-2.50$ & \\
\hline & \multirow[t]{2}{*}{2} & $<1.2 \mathrm{mmol} / \mathrm{L}$ & 177 & 0.85 & $0.43-1.76$ & \multirow[t]{2}{*}{$<0.05$} \\
\hline & & $\geq 1.2 \mathrm{mmol} / \mathrm{L}$ & 120 & 1.65 & $0.68-2.50$ & \\
\hline \multirow[t]{4}{*}{ Calving } & \multirow[t]{2}{*}{1} & $\overline{\text { Spontaneous }}$ & 67 & 2.14 & $1.24-2.50$ & \multirow[t]{2}{*}{0.40} \\
\hline & & Assisted & 79 & 2.35 & $1.56-2.50$ & \\
\hline & \multirow[t]{2}{*}{2} & Spontaneous & 234 & 0.99 & $0.49-2.02$ & \multirow[t]{2}{*}{$<0.05$} \\
\hline & & Assisted & 63 & 1.91 & $0.93-2.50$ & \\
\hline \multirow[t]{4}{*}{ Retained fetal membranes } & \multirow[t]{2}{*}{1} & No & 139 & 2.27 & $1.53-2.50$ & \multirow[t]{2}{*}{0.37} \\
\hline & & Yes & 7 & 1.47 & $0.89-2.50$ & \\
\hline & \multirow[t]{2}{*}{2} & No & 255 & 0.97 & $0.47-2.01$ & \multirow[t]{2}{*}{$<0.05$} \\
\hline & & Yes & 42 & 2.40 & $1.76-2.50$ & \\
\hline \multirow[t]{4}{*}{ Treatment $\leq 5$ DIM } & \multirow[t]{2}{*}{1} & No & 125 & 2.19 & $1.35-2.50$ & \multirow[t]{2}{*}{0.10} \\
\hline & & Yes & 21 & 2.49 & $1.87-2.54$ & \\
\hline & \multirow[t]{2}{*}{2} & No & 274 & 1.02 & $0.49-2.15$ & \multirow[t]{2}{*}{$<0.05$} \\
\hline & & Yes & 23 & 2.47 & $1.66-2.66$ & \\
\hline \multirow[t]{4}{*}{ Acute puerperal metritis $\leq 5$ DIM } & \multirow[t]{2}{*}{1} & No & 107 & 2.15 & $1.20-2.50$ & \multirow[t]{2}{*}{$<0.05$} \\
\hline & & Yes & 39 & 2.50 & $1.66-2.52$ & \\
\hline & \multirow[t]{2}{*}{2} & No & 254 & 0.98 & $0.49-2.04$ & \multirow[t]{2}{*}{$<0.05$} \\
\hline & & Yes & 43 & 2.40 & $1.65-2.50$ & \\
\hline
\end{tabular}

${ }^{1}$ Where 1 = primiparous, $2=$ multiparous.

${ }^{2}$ Interquartile range.

${ }^{3} P$-value from Mann-Whitney U-test for differences between haptoglobin concentrations depending on different variables and parities.

Table 2. Final logistic regression model including all cows and showing odds ratios of parity, elevated BHBA at 5 DIM, calving ease, retained fetal membranes, and acute puerperal metritis $\leq 5$ DIM for elevated serum haptoglobin concentration $(\geq 1.4 \mathrm{~g} / \mathrm{L})$ at 5 DIM

\begin{tabular}{lccc}
\hline Variable & Odds ratio & $95 \%$ CI & $P$-value \\
\hline Parity & & & \\
$\quad$ Multiparous & Referent & & \\
Primiparous & 4.40 & $2.64-7.34$ & $<0.05$ \\
BHBA at 5 DIM & & & \\
$<1.2 \mathrm{mmol} / \mathrm{L}$ & Referent & & \\
$\geq 1.2 \mathrm{mmol} / \mathrm{L}$ & 2.87 & $1.80-4.56$ & $<0.05$ \\
Calving & Referent & & \\
$\quad$ Spontaneous & 1.95 & $1.20-3.19$ & $<0.05$ \\
Assisted & & & \\
Retained fetal membranes & Referent & & \\
$\quad$ No & 3.39 & $1.51-7.61$ & $<0.05$ \\
$\quad$ Yes & & & \\
Acute puerperal metritis $\leq 5 \mathrm{DIM}$ & Referent & & \\
No & 4.70 & $2.33-9.48$ & $<0.05$ \\
Yes & & & \\
\hline
\end{tabular}

Table 3. Final logistic regression model including primiparous cows and showing odds ratios of elevated BHBA at 5 DIM and acute puerperal metritis $\leq 5$ DIM for elevated serum haptoglobin concentration $(\geq 2.49$ $\mathrm{g} / \mathrm{L})$ at 5 DIM

\begin{tabular}{lccc}
\hline Variable & Odds ratio & $95 \% \mathrm{CI}$ & $P$-value \\
\hline BHBA at 5 DIM & & & \\
$<1.2 \mathrm{mmol} / \mathrm{L}$ & Referent & & \\
$\geq 1.2 \mathrm{mmol} / \mathrm{L}$ & 2.39 & $1.1-5.22$ & $<0.05$ \\
Acute puerperal metritis $\leq 5$ DIM & & & \\
No & Referent & & \\
Yes & 2.74 & $1.27-5.92$ & $<0.05$ \\
\hline
\end{tabular}


Table 4. Final logistic regression model including multiparous cows and showing odds ratios of elevated BHBA at 5 DIM, calving ease, retained fetal membranes and acute puerperal metritis $\leq 5$ DIM for elevated serum haptoglobin concentration $(\geq 1.4 \mathrm{~g} / \mathrm{L})$ at 5 DIM

\begin{tabular}{lccc}
\hline Variable & Odds ratio & $95 \%$ CI & $P$-value \\
\hline BHBA at 5 DIM & & & \\
$<1.2 \mathrm{mmol} / \mathrm{L}$ & Referent & & \\
$\geq 1.2 \mathrm{mmol} / \mathrm{L}$ & 2.75 & $1.62-4.66$ & $<0.05$ \\
Calving & & & \\
Spontaneous & Referent & & \\
$\quad$ Assisted & 2.46 & $1.3-4.66$ & $<0.05$ \\
Retained fetal membranes & Referent & & \\
$\quad$ No & 5.51 & $2.21-13.69$ & $<0.05$ \\
Yes & Referent & & \\
Acute puerperal metritis $\leq 5$ DIM & 5.01 & $2.09-12.04$ & $<0.05$ \\
No & & & \\
Yes & &
\end{tabular}

cows with APM had $2.75(P<0.05), 2.46(P<0.05)$, $5.51(P<0.05)$, and $5.01(P<0.05)$ times the odds of elevated Hapto.

\section{DISCUSSION}

The objective of this study was to evaluate whether, in addition to APM, other variables such as periparturient metabolic stress indicated by elevated NEFA and BHBA serum concentrations, calving difficulties, antibiotic treatment within 5 DIM, and RFM were associated with elevated Hapto at 5 DIM.

Primiparous cows had 4.4 times the odds of elevated Hapto at 5 DIM compared with multiparous cows. This is consistent with other findings (Crawford et al., 2005; Humblet et al., 2006; Schneider et al., 2013; Burfeind et al., 2014a) and it was speculated that primiparous cows may be more responsive to inflammatory stress associated with calving than multiparous cows (Schneider et al., 2013) because damage to the uterus, vagina, and vulva may be more severe during first parturition (Humblet et al., 2006). This could also explain why calving difficulties in primiparous cows did not result in increased odds of elevated Hapto at 5 DIM. Burfeind et al. (2014a) suggested that primiparous cows that calve spontaneously might be affected by mild cervical or vaginal trauma that remains undetected but stimulates an inflammatory response that could contribute to greater Hapto concentrations. Therefore, our analysis considered 3 parity groups (i.e., all cows, primiparous cows, multiparous cows) with higher thresholds of Hapto in primiparous cows. Multiparous cows with assisted calving had a 2.46-times-higher risk for elevated Hapto, which is consistent with previous findings (Sabedra, 2012).

Periparturient metabolic stress indicated by elevated BHBA at 5 DIM increased the odds (odds ratio: 2.392.87) of elevated Hapto for all 3 parity groups, which supports the results of Ospina et al. (2010). In contrast to our findings, Dubuc et al. (2010) did not find an association of postpartum BHBA concentrations and the risk of metritis. However, they did not evaluate the association between BHBA and Hapto per se.

In contrast to SCK, periparturient metabolic stress indicated by elevated NEFA at 2 DIM was not associated with a risk for elevated Hapto. This result is in line with the observation that concentrations of NEFA were similar between healthy cows and cows with uterine infections (Schneider et al., 2013) and that an association between postpartum NEFA and metritis was not found (Dubuc et al., 2010). Ospina et al. (2010), however, found elevated risk for metritis, displaced abomasum, and clinical ketosis in cows with elevated postpartum NEFA. Moreover, results from the literature are not consistent regarding an optimal threshold for NEFA and an optimal time for taking samples (Hiss et al., 2009; Dubuc et al., 2010; Ospina et al., 2010; Chapinal et al., 2012).

Multiparous cows with RFM were 5.51 times more likely to have elevated Hapto at 5 DIM than cows without RFM, and odds for RFM were even higher than for APM (odds ratio: 5.01). The presence of RFM supports intrauterine bacterial growth and uterine tissue might be damaged due to potential manual removal (Bolinder et al., 1988), leading to inflammatory processes. Dubuc et al. (2010) also found a strong association between RFM and metritis (odds ratio: 6.25, $P<0.01$ ). However, RFM was not a risk factor for elevated Hapto for primiparous cows. One reason for this could be the small number of primiparous cows with RFM $(\mathrm{n}=7)$.

Acute puerperal metritis was highly associated (odds ratio: 2.74-5.01) with elevated Hapto in all parity groups. These results support previous studies in which a 3- to 7-times-higher risk for metritis was described in cows with elevated postpartum Hapto (Huzzey et al., 2009; Dubuc et al., 2010). It is notable that there 
was a greater association between elevated Hapto and multiparous cows with RFM than between Hapto and multiparous cows with APM.

To conclude, metabolic stress, indicated as SCK as well as calving disorders and RFM in multiparous cows, is associated with Hapto concentration at 5 DIM. This could explain the reduced sensitivity and specificity in the detection of metritic cows (Huzzey et al., 2009; Dubuc et al., 2010; Burfeind et al., 2014a) and has to be considered when using Hapto as a diagnostic tool for the detection of cows with APM. However, APM had high odds ratios, reflecting a strong association between APM and Hapto at 5 DIM.

\section{ACKNOWLEDGMENTS}

We gratefully thank the farm personnel of the dairy farm for the kind cooperation. Furthermore, we thank the staff of the Clinic of Reproduction, Freie Universität Berlin (Germany) for their support during the practical part of the study. Alina Pohl was partially funded by Tiergyn e.V. (Berlin, Germany).

\section{REFERENCES}

Bekana, M., P. Jonsson, T. Ekman, and H. Kindahl. 1994. Intrauterine bacterial findings in postpartum cows with retained fetal membranes. Zentralbl. Veterinarmed. A 41:663-670.

Bertulat, S., C. Fischer-Tenhagen, V. Suthar, E. Möstl, N. Isaka, and W. Heuwieser. 2013. Measurement of fecal glucocorticoid metabolites and evaluation of udder characteristics to estimate stress after sudden dry-off in dairy cows with different milk yields. J. Dairy Sci. 96:3774-3787.

Bolinder, A., B. Seguin, H. Kindahl, D. Bouley, and D. Otterby. 1988. Retained fetal membranes in cows; Manual removal versus nonremoval and its effect on reproductive performance. Theriogenology $30: 45-56$.

Bruun, J., A. K. Ersbøll, and L. Alban. 2002. Risk factors for metritis in Danish dairy cows. Prev. Vet. Med. 54:179-190.

Burfeind, O., I. Sannmann, R. Voigtsberger, and W. Heuwieser. 2014a. Receiver operating characteristic curve analysis to determine the diagnostic performance of serum haptoglobin concentration for the diagnosis of acute puerperal metritis in dairy cows. Anim. Reprod. Sci. 149:145-151.

Burfeind, O., V. S. Suthar, R. Voigtsberger, S. Bonk, and W. Heuwieser. 2011. Validity of prepartum changes in vaginal and rectal temperature to predict calving in dairy cows. J. Dairy Sci. 94:5053-5061.

Burfeind, O., V. S. Suthar, R. Voigtsberger, S. Bonk, and W. Heuwieser. 2014b. Body temperature in early postpartum dairy cows. Theriogenology 82:121-131.

Ceciliani, F., J. J. Ceron, P. D. Eckersall, and H. Sauerwein. 2012 Acute phase proteins in ruminants. J. Proteomics 75:4207-4231.

Chapinal, N., M. E. Carson, S. J. LeBlanc, K. E. Leslie, S. Godden, M. Capel, J. E. P. Santos, M. W. Overton, and T. F. Duffield. 2012. The association of serum metabolites in the transition period with milk production and early-lactation reproductive performance. J. Dairy Sci. 95:1301-1309.

Crawford, R. G., K. E. Leslie, R. Bagg, C. P. Dick, and T. F. Duffield. 2005. The impact of controlled release capsules of monensin on postcalving haptoglobin concentrations in dairy cattle. Can. J. Vet. Res. 69:208-214.
Doepel, L., H. Lapierre, and J. J. Kennelly. 2002. Peripartum performance and metabolism of dairy cows in response to prepartum energy and protein intake. J. Dairy Sci. 85:2315-2334.

Drillich, M., D. Voigt, D. Forderung, and W. Heuwieser. 2007. Treatment of acute puerperal metritis with flunixin meglumine in addition to antibiotic treatment. J. Dairy Sci. 90:3758-3763.

Dubuc, J., T. F. Duffield, K. E. Leslie, J. S. Walton, and S. J. LeBlanc. 2010. Risk factors for postpartum uterine diseases in dairy cows. J. Dairy Sci. 93:5764-5771.

Duffield, T. F., K. D. Lissemore, B. W. McBride, and K. E. Leslie. 2009. Impact of hyperketonemia in early lactation dairy cows on health and production. J. Dairy Sci. 92:571-580.

Duffield, T. F., D. Sandals, K. E. Leslie, K. Lissemore, B. W. McBride, J. H. Lumsden, P. Dick, and R. Bagg. 1998. Efficacy of monensin for the prevention of subclinical ketosis in lactating dairy cows. J. Dairy Sci. 81:2866-2873.

Eckersall, P. D. 2000. Recent advances and future prospects for the use of acute phase proteins as markers of disease in animals. Rev. Med. Vet. (Toulouse) 7:577-584.

Galvão, K. N., M. J. B. F. Flaminio, S. B. Brittin, R. Sper, M. Fraga, L. Caixeta, A. Ricci, C. L. Guard, W. R. Butler, and R. O. Gilbert. 2010. Association between uterine disease and indicators of neutrophil and systemic energy status in lactating Holstein cows. J. Dairy Sci. 93:2926-2937.

Gilbert, R. O., N. R. Santos, K. N. Galvão, S. B. Brittin, and H. B Roman. 2007. The relationship between postpartum uterine bacterial infection (bi) and subclinical endometritis (se). J. Dairy Sci. 90(Suppl. 1):469-470. (Abstr).

Goff, J. P., and R. L. Horst. 1997. Physiological changes at parturition and their relationship to metabolic disorders. J. Dairy Sci. 80:1260-1268.

Halpern, N. E., H. N. Erb, and R. David Smith. 1985. Duration of retained fetal membranes and subsequent fertility in dairy cows. Theriogenology 23:807-813.

Hammon, D. S., I. M. Evjen, T. R. Dhiman, J. P. Goff, and J. L. Walters. 2006. Neutrophil function and energy status in holstein cows with uterine health disorders. Vet. Immunol. Immunopathol. 113:21-29.

Hellmann, K., and I. Radeloff. 2000. Guidance for industry: Good clinical practice. International Cooperation on Harmonisation of Technical Requirements for Registration of Veterinary Medicinal Products (VICH). VICH, Brussels, Belgium. http://www.fda.gov/ downloads/AnimalVeterinary/GuidanceComplianceEnforcement/ GuidanceforIndustry/UCM052417.pdf.

Hiss, S., C. Weinkauf, S. Hachenberg, and H. Sauerwein. 2009. Short communication: Relationship between metabolic status and the milk concentrations of haptoglobin and lactoferrin in dairy cows during early lactation. J. Dairy Sci. 92:4439-4443.

Humblet, M.-F., H. Guyot, B. Boudry, F. Mbayahi, C. Hanzen, F. Rollin, and J.-M. Godeau. 2006. Relationship between haptoglobin, serum amyloid a, and clinical status in a survey of dairy herds during a 6-month period. Vet. Clin. Pathol. 35:188-193.

Hussain, A. M. 1989. Bovine uterine defense mechanisms: A review. Zentralbl. Veterinarmed. B 36:641-651.

Huzzey, J. M., T. F. Duffield, S. J. LeBlanc, D. M. Veira, D. M. Weary, and M. A. G. von Keyserlingk. 2009. Short communication: Haptoglobin as an early indicator of metritis. J. Dairy Sci. 92:621-625.

Iwersen, M., U. Falkenberg, R. Voigtsberger, D. Forderung, and W. Heuwieser. 2009. Evaluation of an electronic cowside test to detect subclinical ketosis in dairy cows. J. Dairy Sci. 92:2618-2624.

LeBlanc, S. 2010. Monitoring metabolic health of dairy cattle in the transition period. J. Reprod. Dev. 56:S29-S35.

LeBlanc, S. J. 2008. Postpartum uterine disease and dairy herd reproductive performance: A review. Vet. J. 176:102-114.

McArt, J. A. A., D. V. Nydam, and G. R. Oetzel. 2012. Epidemiology of subclinical ketosis in early lactation dairy cattle. J. Dairy Sci. 95:5056-5066.

McArt, J. A. A., D. V. Nydam, G. R. Oetzel, T. R. Overton, and P. A. Ospina. 2013. Elevated non-esterified fatty acids and $\beta$-hydroxybutyrate and their association with transition dairy cow performance. Vet. J. 198:560-570. 
Ospina, P. A., D. V. Nydam, T. Stokol, and T. R. Overton. 2010. Evaluation of nonesterified fatty acids and $\beta$-hydroxybutyrate in transition dairy cattle in the northeastern united states: Critical thresholds for prediction of clinical diseases. J. Dairy Sci. 93:546-554

Sabedra, D. A. 2012. Serum haptoglobin as an indicator for calving difficulties and postpartal diseases in transition dairy cows. Undergraduate Thesis. Oregon State University, Corvallis.

Sannmann, I., O. Burfeind, R. Voigtsberger, and W. Heuwieser. 2013. Comparison of two monitoring and treatment strategies for cows with acute puerperal metritis. Theriogenology 79:961-969.

Schneider, A., M. N. Correa, and W. R. Butler. 2013. Short communication: Acute phase proteins in Holstein cows diagnosed with uterine infection. Res. Vet. Sci. 95:269-271.
Sheldon, I. M., G. S. Lewis, S. LeBlanc, and R. O. Gilbert. 2006. Defining postpartum uterine disease in cattle. Theriogenology 65:1516-1530.

Suthar, V. S., J. Canelas-Raposo, A. Deniz, and W. Heuwieser. 2013. Prevalence of subclinical ketosis and relationships with postpartum diseases in European dairy cows. J. Dairy Sci. 96:2925-2938.

Uchida, E., N. Katoh, and K. Takahashi. 1993. Induction of serum haptoglobin by administration of ethionine to cows. J. Vet. Med. Sci. 55:501-502. 